\title{
Kahramanmaraş İlinde Su Kirliliğinin Çiftçiler Üzerine Etkileri*
}

\author{
Emine İKİKAT TÜMER \\ Kahramanmaraş Sütçü İmam Üniversitesi Ziraat Fakültesi, Tarım Ekonomisi Bölümü, Kahramanmaraş \\ (Sorumlu Yazar e-mail : 2katumer@gmail.com)
}

Geliş Tarihi :04.11.2016

Kabul Tarihi : 15.03.2017

\begin{abstract}
ÖZET : Son yüzyılda tarımsal üretimde yoğun girdi kullanımı, kentleşme ve sanayileşmenin hızlı bir şekilde artmasıyla toprak, hava ve su hızla kirlenmeye başlamıștır. Su kirliliği tarımsal üretimde verim ve kalite kaybı ile birlikte üretici gelirinin azalmasına neden olmaktadır. Bu çalışmada Kahramanmaraş ilinde su kirliliğinin olduğu bölgede çiftçilerin sosyo-ekonomik özellikleri ve su kirliliğine karşı tutum ve davranışlarının ortaya konulması amaçlanmıştır. Bu amaçla araştırma bölgesi kirli ve temiz olmak üzere iki bölüme ayrılmış ve bölgede 236 çiftçi ile görüşülmüştür. Araştırmaya katılan bireylerde cilt hastalığı görülme oranı kirli bölgede (\%18.4) temiz bölgeden (\%15.4) \%3.0 daha fazladır. Temiz bölgede tarımsal üretim yapan çiftçilerin \%87.3'ü ve kirli bölgede üretim yapanların \%90.0'1 sağlıklı gelecek nesiller yetiştirebilmek ve onlara işletmelerini devredebilmek amacıyla ekonomik açıdan karlı ve verimli, çevre, insan ve hayvan sağlığına zarar vermeyen bir üretim biçimi olan İyi Tarım Uygulamalarını yapmak istemektedirler.
\end{abstract}

Anahtar kelimeler: Su, kirlilik, Aksu nehri, Kahramanmaraş

\section{Effects on Farmers of Water Pollution in Kahramanmaras Province}

\begin{abstract}
In the last century, with the rapid increase of urbanization and industrialization, the intensive use of inputs in agricultural production, land, air and water have started to become polluted rapidly. Water pollution leads to a decrease in producers' income together with loss of productivity and quality in agricultural production. In this study, it was aimed to reveal the socio-economic characteristic and attitudes and behaviors of the farmers towards water pollution in Kahramanmaras Province. For this purpose, the research area divided in two regions which are called dirty and clean and interviewed with 236 farmers in this region. Individuals participating in this research, the incidence rate of skin disease in dirty region $(18.4 \%)$ is $3.0 \%$ more than in clean region (15.4\%). $87.3 \%$ of farmers in clean region and $\% 90$ of farmers in dirty region prefer to do Good Agricultural Practices which is a form of production that is economically profitable and productive, do not harm environment, human and animal health in order to raise healthy generations and enable them to operate farmer's business.
\end{abstract}

Keywords: Water, pollution, Aksu river, Kahramanmaraş.

GíRiş

19. yüzyılın başlarından itibaren sanayi ve teknolojik ilerleme, hızlı nüfus artışı, kırsal alanlardan kente göç, çarpık şehirleşme, turizm, tarımsal üretimde bilinçsiz girdi kullanımı, nükleer denemeler, bölgesel savaşlar, doğal alanların tahribi gibi faaliyetler (Imandoust ve Gadam 2007; Shang vd., 2012) ile insanoğlunun yaşadığı çevreye müdahalesi (Toroğlu vd. 2006) doğanın kendini yenileme kapasitesinin üzerine çıkmasına neden olmuştur. Bu durum toprak, hava ve su kirliliği, ozon tabakasının incelmesi, biyoçeşitliliğin azalması, asit yağmurları gibi çevre sorunlarını da beraberinde getirmiştir (Brown, 1991; MacNeill vd., 1992; Goodland, 1996; Görmez, 1997; Kates, 2000; Tietenberg ve Lewis, 2009).

Çevre kirliliği, bütün canlıların sağlığını olumsuz yönde etkileyen, canlı ve cansız çevre öğeleri üzerinde yapısal zararlar meydana getiren ve niteliklerini bozan yabancı maddelerin hava, su ve toprağa yoğun bir şekilde karışması olarak tanımlanmaktadır (Kavas, 2011; Çepel ve Ergün, 2013). Toprak kirliliğine neden olan etmenler hava ve su kirliliğinin bir sonucudur. Gelecek kuşaklara temiz bir çevre bırakmak için öncelikle hava ve su temizliğine önem vermek gerekir.
Su kirliliği, çok sayıda göl ve akarsu ile tatlı su potansiyeline sahip olan Türkiye'nin değil, aynı zamanda tüm dünya ülkelerinin de çözmesi gereken en önemli çevre sorunlarından biridir.Türkiye'de özellikle nehir, akarsu, çay gibi su ortamları, atıkların çoğu için ideal bir deşarj yeri olarak kabul edilmiş, basit ve ucuz bir bertaraf seçeneği olarak geniş uygulama görmüştür. Gelişmiş ülkeler de dahil olmak üzere kabul edilen bu kavram zehirli kimyasal maddelerin biyolojik birikiminin ve bazı kirleticilerin su ortamlarında uzun süre kalması nedeniyle ekolojik zehirlenmenin artarak bugünkü vahim duruma gelmesine yol açmıştır. Bu kirlenme suyun fiziksel, kimyasal ve biyolojik özelliklerini etkilemektedir (Taylan ve Özkoç, 2007).

Türkiye'de kirlenen Ergene Nehri sularıla sulanan tarım arazilerinde ürün verim ve kalitesi kirlilikten olumsuz yönde etkilendiği (Kocaman vd. 2011), tarım, sanayi ve kentsel atıkların drene edildiği Aksu nehrinden sulanan tarım arazilerinden elde edilen ürünler ve Aksu nehri, Karaçay, Erkenez ve özellikle Sır barajında yetişen balıklar içerdikleri bakteri, ağır metal ve patojenler (Alonso vd., 1999; Toroglu vd., 2005; Toroglu vd., 2009) ile insan sağlığını tehdit ettiği çeşitli çalışmalarla ortaya konulmuştur. Türkiye'de akarsuların kirlilik 
nedenleri, kirlilik seviyeleri, bu seviyelerde sucul ortama verilen zararlar, tarım, sanayi ve kentleşmenin akarsulara etkileri konusunda birçok çalışma yapılmıştır. Ancak su kirliliğinden etkilenen çiftçilerin tutum ve davranışlarını inceleyen çalışmalara literatürde rastlanmamıştır.

$\mathrm{Bu}$ çalışmada Kahramanmaraş ilinde Aksu nehri, Karaçay ve Erkenez çayları üzerinde kirliliğinin olduğu bölgede çiftçilerin sosyoekonomik özellikleri ve su kirliliğine karşı tutum ve davranışlarının ortaya konulması amaçlanmıştır.

\section{MATERYAL ve METOT}

Çalışmanın ana materyalini Aksu nehri ve Aksu nehrini besleyen Karaçay ve Erkenez çaylarının bulunduğu Kahramanmaraş ili Merkez, Türkoğlu ve Pazarcık ilçelerinde tarımsal üretim yapan çiftçiler oluşturmaktadır. Sonlu bir popülasyon için belli bir özelliği taşıyanların bilinen veya tahmin edilen oranına göre örnek hacmi Oransal Örnekleme Yöntemi ile hesaplanmıştır (Newbold, 1995).

$$
n=\frac{N * p^{*}(1-p)}{(N-1) * \sigma_{p}^{2}+p *(1-p)} \cong 236
$$

Formülde; n:Örnek büyüklüğü, N:Aksu nehrinden sulama yapan işletme sayısı, $\sigma_{\mathrm{p}}^{2}$ : Oranın varyans1, r: Ortalamadan sapma $(\% 5), \mathrm{Z}_{\alpha / 2}: \mathrm{z}$ cetvel değeri (1.645), p: Aksu nehrinin kirli bölümünden sulama yapan işletmelerin oranını göstermektedir. Burada $\% 90$ güven aralığında $(z=1.645)$ ve ortalamadan $\% 5$ sapma ile anket yapılacak örnek işletme sayısı 236 olarak hesaplanmıştır. Araştırma bölgesinde yapılan anketler çalışmanın birincil verilerini oluşturmaktadır.
Tanrıverdi ve ark. (2010), Ceyhan Nehri havzasının yüzey su kalitesini araştırmak amacıyla 3 aylık periyotlarla 31 istasyonda suyun 13 fizikokimyasal parametresini incelemişler ve analizler sonucunda Erkenez çayının Aksu nehrine bağlandığ1 bölgenin 31 nolu istasyonun (Erkenez 2) en yüksek $\mathrm{pH}$ değerine sahip olduğunu belirlemişlerdir. Erkenez 2, Aksu 4 (Aksu Nehri üzerinde fabrikaların kurulmaya başladığı bölge) ve Sır 2 (Aksu Nehrinin Sır barajına bağlantı noktası) istasyonlarının iletkenliğin en fazla olduğu bölge olduğunu tespit etmişlerdir. İletkenliğin ve $\mathrm{pH}$ değerinin yüksek olmasını ise sanayi atıklarının, artan nüfus ile birlikte evsel atıkların Erkenez çayı ve Aksu nehrine drene edilmesi olabileceğini ifade etmişlerdir. $\mathrm{Bu}$ çalışmanın sonuçlarından yola çıkılarak araştırma bölgesi kirli ve temiz olmak üzere ikiye ayrılmıştır.

\section{ARAŞTIRMA BULGULARI}

Araştırma bölgesindeki çiftçilerin yaşları ortalama $52.70 \mathrm{y} 1$, ortalama eğitim süreleri $6.65 \mathrm{y} 1$, ortalama hanehalkı birey sayısı 4.71 kişi, tarımda çalışan birey sayısı ortalama 1.72 kişi ve tarımsal üretim tecrübeleri ortalama 29.80 y1l olarak hesaplanmıştır. Çiftçilerin sahip olduğu ortalama arazi büyüklüğü 188.19 da olarak tespit edilmiştir. Ankete katılanlar y1llik 700 TL ile 500000 TL arasında gelir elde etmekte olup ortalama 75102.27 TL yıllık gelire sahiptirler. Çiftçilerin \%71.0'i tarım dış1 işte çalışmakta ve y1llık ortalama 20579.36 TL gelir elde etmektedirler. Ankete katılanların \%43.7'sinin 2014 y1lına ait borcu bulunmakta ve ortalama borçları 55093.46 TL olarak hesaplanmıştır (Çizelge 1).

Çizelge 1. Çiftçilerin sosyo-demografik özellikleri.

\begin{tabular}{lrrrr} 
& Minimum & Maksimum & Ortalama & Std. Sapma \\
\hline Yaş (yıl) & 20 & 77 & 52.70 & 12.61 \\
Eğitim (yıl) & 0 & 15 & 6.65 & 2.98 \\
Hanehalkı birey (kişi) & 2 & 15 & 4.71 & 2.00 \\
Tarımda çalışan birey (kişi) & 1 & 7 & 1.72 & 1.01 \\
Tecrübe (yıl) & 1 & 60 & 29.80 & 13.70 \\
Arazi (da) & 2 & 2520 & 188.19 & 314.50 \\
Gelir (TL/yıl) & 700 & 500000 & 75102.27 & 103913.54 \\
Tarım diş1 gelir (yıl) & 1200 & 400000 & 20579.36 & 39884.43 \\
2014 yılına ait borç (TL) & 100 & 600000 & 55093.46 & 89174.09 \\
\hline
\end{tabular}

Araştırma bölgesinde ankete katılan çiftçilerin \%71.0'i tarımsal üretim dışında herhangi bir işte çalışmakta ve \%11.4'ünün ise tarımsal işletme dışında yatırım yaptığı tespit edilmiştir. Çiftçilerin $\% 89.0$ 'u sosyal güvenceye sahipken, \%11.0'i herhangi bir sosyal güvenceye sahip değildir (Çizelge 2). Bu oran Türkiye genelinde $\% 81.9$ olan sigortalılık oranının üzerindedir (Anonim 2015a). Ankete katılanların \%47.3'ü herhangi bir kooperatife, \%29.4'ü ise herhangi bir üretici birliğine üyedir. 
Çiftçilerin \%65.3'ü organik ürünün tanımını bilmekte, \%40.6's1 organik ürün üretmek istemekte, \%24.6's1 İyi Tarım Uygulamaları hakkında bilgi sahibi ve \%87.3'ü İyi Tarım Uygulamalarını tatbik etmek istemektedirler (Çizelge 2). Organik üretimde girdi maliyetlerinin yüksek, üretilen ürün fiyatlarının düşük olması ile birlikte organik ürünlerin pazarının bulunmaması organik tarımın uygulanmak istenmeme sebeplerinin başında gelmektedir.

Çizelge 2. Çiftçilere ait özellikler (\%)

\begin{tabular}{lcc} 
& Hayır & Evet \\
\hline Tarım dışı işte çalışma & 29.0 & 71.0 \\
Tarım dışı yatırım & 88.6 & 11.4 \\
Sosyal Güvence & 11.0 & 89.0 \\
2014 yılına ait borç & 56.3 & 43.7 \\
Kooperatife üyelik & 52.7 & 47.3 \\
Üretici birliğine üyelik & 70.6 & 29.4 \\
Organik ürünün tanımını bilme & 34.7 & 65.3 \\
Organik ürün üretme isteği & 59.4 & 40.6 \\
İyi tarım uygulamaları hakkında bilgi & 75.4 & 24.6 \\
İyi tarım uygulamaları yapma isteği & 12.7 & 87.3 \\
\hline
\end{tabular}

Araştırma bölgesinde anket yapılan çiftçilerin \%42.4'ü Aksu nehri ve onu besleyen çayların henüz kirlenmemiş, diğer bir ifadeyle temiz bölgede, \%57.6's1 ise çeşitli nedenlerle kirlenmiş ve bu kirliliğin bilimsel olarak ortaya konulduğu kirli bölgede üretim yapmaktadırlar. Ankete katılan ve temiz su ile tarımsal üretimi gerçekleştiren çiftçilerin \%39.4'ü 59 yaşından fazla iken kirli suyu kullanan çiftçilerin \%34.8'i 45 yaşın altındadır. Bunun yanı sıra bölgede yaş arttıkça kirli su ile tarımsal üretim yapanların oranı azalmaktadır. Başka bir deyişle su kirliliği arttıkça, suyun temiz halini kullanmış olan ya da kirliliğin her geçen gün arttığını gören orta yaşın üzerindeki çiftçiler tarımsal üretimi daha az yapmak istemektedirler. Araştırma yapılan bölgede ilkokul mezunu olan çiftçilerin \%69.2'si temiz, \%64.5'i ise kirli bölgede bulunmaktadır (Çizelge 3). Çiftçi ailelerinde ortalama hanehalkı birey sayıs1 4.71 birey olup bunun 1.72 bireyi tarımsal üretimde çalışmaktadır (Çizelge 1). Temiz bölgedeki çiftçilerin \%62.5'inde hanehalkından bir birey tarımsal üretimde bulunurken, kirli bölgede çiftçilerin \%59.6'sının hanehalkından 2 ve daha fazla birey tarımsal üretimde bulunmaktadır. Kirli bölgede temiz suya ulaşmak diğer bölgeye göre daha masraflı ve zahmetli olmaktadır. Kirli bölgede Aksu nehri ya da arklarından sulama yapmak genellikle mümkün olmamakta ve kuyu suyu kullanılmaktadır. Ayrıca çiftçiler tarafından kirlilikten dolayı ürün verim ve kalitesinde düşüşler gözlemlenmektedir. Sabit masrafları dikkate almayan çiftçi aile işgücünü artırarak ürün verim ve kalitesini artırarak gelirini artırmanın yollarını aramaktadır. Dolayısıyla bu bölgede tarımsal üretimde yer alan hanehalkında birden fazla kişiye ihtiyaç duyulmaktadır. Kirli bölgede üretim yapan çiftçilerin $\% 60.3$ 'ünün arazi varlığ 100 da'dan daha azdır. Temiz bölgedeki çiftçilerin ise \%56.7'sinin arazi varlığ 100 da'dan fazladır. Kirli bölgedeki çiftçiler ürünlerini sulayamamakta, kirlilikten dolayı ürün verim ve kalitesinde azalış olduğu için arazilerini satmaya başlamışlardır (Çizelge 3).

Yıllık ortalama yaklaşık 75000 TL gelir elde eden çiftçilerden temiz bölgede üretim yapanların $\% 54.8$ 'i kirli bölgede tarımsal üretim yapanların \%37.6's1 15000 TL ile 99000 TL arasında gelir elde etmektedir. Kirli bölgede düşük gelirli çiftçilerin oranının fazla olmasının en önemli nedenlerinden birisi temiz suya ulaşım sorunudur. Bölgede çiftçilerin \%89'unun sosyal güvencesi ve \%11.4'ünün tarım dışı yatırımı bulunmaktadır (Çizelge 3). Arazi varlığ 100 da altında olan işletme sayısı, sosyal güvence ve tarım dışı yatırım yapma durumunun kirli bölgede daha fazla olması gelir düşüklüğünün nedenini açıklamaktadır. Arazi varlığının azlığı, sosyal güvencenin olması çiftçinin tarım dışı işlerle uğraştığını ve köy dişında yatırım yaptığını göstermektedir.

Araştırma bölgesinde çiftçilerin \%47.3'ü herhangi bir kooperatife üye olup, temiz suyun bulunduğu bölgede tarımsal üretim yapan çiftçilerin $\% 57.7$ 'si herhangi bir kooperatife üye iken kirli suyun bulunduğu bölgede tarımsal üretim yapan çiftçilerin \%60.3'ü herhangi bir kooperatife üye değildir. Bölgede çiftçilerin \%70.6'sının herhangi bir üretici birliğine üyelikleri bulunmamaktadır (Çizelge 3). 
Çizelge 3. Su kirliliği açısından çiftçi özellikleri (\%).

\begin{tabular}{|c|c|c|c|c|}
\hline & & Temiz & Kirli & Toplam \\
\hline \multirow{4}{*}{ Yaş } & $<45$ & 23.1 & 34.8 & 29.8 \\
\hline & $45-59$ & 37.5 & 34.0 & 35.5 \\
\hline & $60+$ & 39.4 & 31.2 & 34.7 \\
\hline & Toplam & 100.0 & 100.0 & 100.0 \\
\hline \multirow{6}{*}{ Eğitim } & Okur yazar olmayan & 1.0 & 2.1 & 1.6 \\
\hline & İlkokul mezunu & 69.2 & 64.5 & 66.5 \\
\hline & Orta okul mezunu & 14.4 & 9.9 & 11.8 \\
\hline & Lise mezunu & 9.6 & 18.4 & 14.7 \\
\hline & Üniversite mezunu & 5.8 & 5.0 & 5.3 \\
\hline & Toplam & 100.0 & 100.0 & 100.0 \\
\hline \multirow{3}{*}{ Tarımda çalışan birey sayısı } & 1 & 62.5 & 40.4 & 49.8 \\
\hline & $2+$ & 37.5 & 59.6 & 50.2 \\
\hline & Toplam & 100.0 & 100.0 & 100.0 \\
\hline \multirow{3}{*}{ Arazi varlığı (da) } & $<100$ & 43.3 & 60.3 & 53.1 \\
\hline & $100+$ & 56.7 & 39.7 & 46.9 \\
\hline & Toplam & 100.0 & 100.0 & 100.0 \\
\hline \multirow{4}{*}{ Gelir } & $<15000$ & 20.2 & 39.7 & 31.4 \\
\hline & $15000-99000$ & 54.8 & 37.6 & 44.9 \\
\hline & $100000+$ & 25.0 & 22.7 & 23.7 \\
\hline & Toplam & 100.0 & 100.0 & 100.0 \\
\hline \multirow{3}{*}{ Sosyal Güvence } & Hayır & 13.5 & 9.2 & 11.0 \\
\hline & Evet & 86.5 & 90.8 & 89.0 \\
\hline & Toplam & 100.0 & 100.0 & 100.0 \\
\hline \multirow{3}{*}{ Tarım Dışı Yatırım } & Hayır & 93.3 & 85.1 & 88.6 \\
\hline & Evet & 6.7 & 14.9 & 11.4 \\
\hline & Toplam & 100.0 & 100.0 & 100.0 \\
\hline \multirow{3}{*}{ Kooperatife üye olma } & Hayır & 42.3 & 60.3 & 52.7 \\
\hline & Evet & 57.7 & 39.7 & 47.3 \\
\hline & Toplam & 100.0 & 100.0 & 100.0 \\
\hline \multirow{3}{*}{ Üretici birliğine üye olma } & Hayır & 63.5 & 75.9 & 70.6 \\
\hline & Evet & 36.5 & 24.1 & 29.4 \\
\hline & Toplam & 100.0 & 100.0 & 100.0 \\
\hline \multirow{3}{*}{ Organik ürün üretme isteği } & Hayır & 69.2 & 52.1 & 59.4 \\
\hline & Evet & 30.8 & 47.9 & 40.6 \\
\hline & Toplam & 100.0 & 100.0 & 100.0 \\
\hline \multirow{3}{*}{$\begin{array}{l}\text { İyi Tarım Uygulamaları hakkında } \\
\text { bilgi sahibi olma }\end{array}$} & Hayır & 73.1 & 77.1 & 75.4 \\
\hline & Evet & 26.9 & 22.9 & 24.6 \\
\hline & Toplam & 100.0 & 100.0 & 100.0 \\
\hline \multirow{3}{*}{$\begin{array}{l}\text { İyi Tarım Uygulamaları yapma } \\
\text { isteği }\end{array}$} & Hayır & 16.3 & 10.0 & 12.7 \\
\hline & Evet & 83.7 & 90.0 & 87.3 \\
\hline & Toplam & 100.0 & 100.0 & 100.0 \\
\hline
\end{tabular}

Araştırma bölgesindeki çiftçilerin \%59.4'ü organik girdi temin zorluğu, bölgenin organik ürün üretimine uygun olmaması, temiz su bulma güçlüğü, verim kaybı endişesi gibi nedenlerle organik ürün üretmek istememektedir. Kirli bölgede tarımsal üretim yapanların temiz bölgeye göre daha fazla organik ürün üretmek istemelerinin en önemli nedenleri arasında; bölgenin organik ürün üretmek için uygun şartların sağlanmasında Aksu nehri ve onu besleyen çayların temizleneceği düşüncesi, fabrika ve şehir atıklarının arıtılarak nehirlere bırakılacak olması, tarımda yoğun girdi kullanımının azalacağının tahmin edilmesi sayılabilir (Çizelge 3). İyi Temiz bölgedeki çiftçilerin \%87.3'ü, kirli bölgede tarımsal üretim yapanların \%90.0'1 ve temiz bölgedekilerin \%83.7'si sağlıklı gelecek nesiller yetiştirebilmek ve onlara işletmelerini devredebilmek amacıyla ekonomik açıdan karlı ve verimli, çevre, 
insan ve hayvan sağlığına zarar vermeyen bir üretim biçimi olan İTU'nı yapmak istemektedirler (Çizelge $3)$.

Kahramanmaraş ili 2014 yılı Ocak ayında büyükşehir olduğu için 2015 yılından sonra mahalle olan köylere belediye hizmetleri ulaşmaya başlamıştır. İl Büyükşsehir belediyesi olmadan önce çöplerin \%25.9'u akarsu, dere veya çaylara, \%65.0'i ise arazilerdeki boş alanlara atılmaktadır. Büyükşehir belediyesi olduktan sonra ise çöplerini çöp kutusuna atanların oranı \%89.4 olarak hesaplanmıştır. Kirli bölgede çöplerini çöp kutusuna atanların oranı \%90.8 olarak belirlenmiştir. Temiz bölgede ise bu oran \%87.5 olarak hesaplanmıştır. Kirli bölgede yaşayan çiftçiler temiz bölgede yaşayanlara göre çöplerin çöp kutusuna atılması konusunda daha hassas davranmaktadırlar. Araştırma bölgesindeki çiftçilerin \%73.8'i atıkların doğada yok olma süreleri hakkında bilgi sahibi değildirler. Bölgede tarımla uğraşan bireylerde cilt hastalığı görülme oranı kirli bölgede (\%18.4) temiz bölgeden (15.4) \%3.0 daha fazladır (Çizelge 4).

Özellikle kirli bölgede hayvanlarını karşıdan karşıya geçirmek için Aksu Nehri ve onu besleyen çayları kullanmak zorunda olan çiftçiler, hayvanların ayaklarında yara çıktığını ve bir süre sonra da yürüme güçlüğü çektiğini ifade etmişlerdir.

Çizelge 4. Su kirliliği açısından çiftçi özellikleri (\%)

\begin{tabular}{|c|c|c|c|c|}
\hline & & Temiz & Kirli & Toplam \\
\hline \multirow{4}{*}{$\begin{array}{l}\text { Büyüksşehir belediyesi olmadan } \\
\text { önce çöp alanı }\end{array}$} & Akarsu, dere, çay & 16.5 & 32.9 & 25.9 \\
\hline & Arazide boş alana & 77.7 & 55.7 & 65.0 \\
\hline & Çukur açıp gömme & 5.8 & 11.4 & 9.1 \\
\hline & Toplam & 100.0 & 100.0 & 100.0 \\
\hline \multirow{3}{*}{$\begin{array}{l}\text { Büyükşehir belediyesi olduktan } \\
\text { sonra çöp alanı }\end{array}$} & Diğerleri & 12.5 & 9.2 & 10.6 \\
\hline & Çöp kutusu & 87.5 & 90.8 & 89.4 \\
\hline & Toplam & 100.0 & 100.0 & 100.0 \\
\hline \multirow{3}{*}{$\begin{array}{l}\text { Atıkların yok olma süreleri } \\
\text { hakkında bilgi }\end{array}$} & Hayır & 76.9 & 71.4 & 73.8 \\
\hline & Evet & 23.1 & 28.6 & 26.2 \\
\hline & Toplam & 100.0 & 100.0 & 100.0 \\
\hline \multirow{3}{*}{$\begin{array}{l}\text { Tarımla uğraşan bireylerde cilt } \\
\text { hastalığı görülme durumu }\end{array}$} & Hayır & 84.6 & 81.6 & 82.9 \\
\hline & Evet & 15.4 & 18.4 & 17.1 \\
\hline & Toplam & 100.0 & 100.0 & 100.0 \\
\hline \multirow{3}{*}{$\begin{array}{l}\text { Gübre miktarının belirlenmesinde } \\
\text { toprak analizi }\end{array}$} & Hayır & 46.2 & 69.5 & 59.6 \\
\hline & Evet & 53.8 & 30.5 & 40.4 \\
\hline & Toplam & 100.0 & 100.0 & 100.0 \\
\hline \multirow{3}{*}{ Derin kuyu bulunma } & Diğerleri & 44.2 & 23.4 & 32.2 \\
\hline & Derinkuyu & 55.8 & 76.6 & 67.8 \\
\hline & Toplam & 100.0 & 100.0 & 100.0 \\
\hline \multirow{3}{*}{ Derin kuyu DSI belgesi } & Hayır & 23.3 & 37.2 & 32.4 \\
\hline & Evet & 76.7 & 62.8 & 67.6 \\
\hline & Toplam & 100.0 & 100.0 & 100.0 \\
\hline \multirow{5}{*}{ Sulama yöntemi } & Karık & 14.6 & 29.0 & 22.8 \\
\hline & Damla & 5.8 & 8.0 & 7.1 \\
\hline & Yağmurlama & 6.8 & 2.9 & 4.6 \\
\hline & Salma(tava) & 72.8 & 60.1 & 65.6 \\
\hline & Toplam & 100.0 & 100.0 & 100.0 \\
\hline \multirow{4}{*}{ Toprak analizi yaptırma sıklığ } & Hayır & 26.9 & 46.4 & 38.1 \\
\hline & Çok nadir & 23.1 & 15.0 & 18.4 \\
\hline & Her y1l & 50.0 & 38.6 & 43.4 \\
\hline & Toplam & 100.0 & 100.0 & 100.0 \\
\hline \multirow{3}{*}{$\begin{array}{l}\text { Toprak analizi desteğinden } \\
\text { faydalanma }\end{array}$} & Hayır & 30.8 & 50.7 & 42.2 \\
\hline & Evet & 69.2 & 49.3 & 57.8 \\
\hline & Toplam & 100.0 & 100.0 & 100.0 \\
\hline
\end{tabular}


Araştırma bölgesindeki çiftçilerin \%59.6's1 yetiştirdikleri ürünün ihtiyacı olan gübre miktarını belirlerken toprak analizini dikkate almamaktadırlar. Kirli bölgedeki çiftçilerin \%36.6's1 toprak analizi yaptırmakta ve \%69.5'i kullanacakları gübre miktarını belirlerken bu analiz sonucunu dikkate almamaktadırlar. Bunun en önemli nedenleri arasında toprak analizinin öneminin çiftçiler tarafından kavranmamış olması ve yapılan analiz sonuçlarına çiftçilerin güvenmemesi sayılabilir (Çizelge 4).

Kirli bölgedeki çiftçilerin \%76.6's1 ürünlerini temiz sulamak amaciyla derin kuyu kullanmakta ve \%62.8'inin DSİ'den derin kuyu açma belgesi bulunmaktadır. Bölgede çiftçiler genellikle salma sulama yöntemini (\%65.6) tercih etmektedirler. Çiftçiler damla ve yağmurlama sulamanın yapılışı ve avantajları konusunda bilgilendirilirse daha az su kullanarak üretimlerini gerçekleştirebilecek ve bölgede daha az yeraltı su kaynakları kullanılmış olacaktır (Çizelge 4).

\section{SONUÇ VE ÖNERILLER}

Gelişmekte olan ülkelerde nüfusun gida ihtiyacının karşılanması, ülke ekonomisine katkı sağlanması, nüfusun belirli bir kesimine iş imkanı sunulması, gelişen teknoloji ile birlikte sanayiye hammadde temini gibi nedenlerle tarımsal üretimde birim alandan daha fazla ürün elde etmek hedeflenmiştir. Bu amaçla çiftçiler tarımsal üretimde yoğun girdi kullanmışlardır. Tarımda yoğun girdi kullanımı, kentleşme, sanayileşme ve küresel ısınmanın da etkisiyle doğal kaynaklar hızla kirlenmeye başlamıştır. Bu durum özellikle yerleşim yerleri ve sanayi atıklarının doğal drenaj yeri olarak bilinen akarsuların daha fazla kirlenmesine neden olmuştur. Bu çalışmada Kahramanmaraş ilinde Aksu nehri, Karaçay ve Erkenez çayları üzerinde kirliliğinin olduğu bölgede çiftçilerin sosyoekonomik özellikleri ve su kirliliğine karşı tutum ve davranışlarının ortaya konulması amaçlanmıştır.

Araştırma sonuçlarına göre temiz bölgeye göre kirli bölgede eğitim seviyesi daha yüksek, tarımda çalışan birey sayısı daha fazla olmakla birlikte arazi büyüklügü ve tarımsal üretimden elde edilen gelir seviyesi düşüktür. Bunun yanı sıra kirli bölgedeki çiftçiler çevre, insan, bitki ve hayvan sağlı̆̆ına zarar vermeyen bir tarımsal üretimin yapılması, doğal kaynakların korunması hedeflerini taşıyan İyi Tarım Uygulamalarının yaygınlaşmasına destek vererek bölge kirliliğinin azaltılmasına katkı sağlamak istemektedirler. $\mathrm{Bu}$ çiftçiler İTU hakkında bilgilendirilmeli ve örnek çiftçilerle bir araya getirilerek bu konuda bilinçlendirilmeleri sağlanmalıdır.

Bölgedeki çiftçilerin yaklaşık \%11'i çöplerini çöp kutuları yerine akarsu, dere, çay veya arazide boş alana atmakta ve \%73.8'i de atıkların yok olma sürelerini bilmemektedirler. Çiftçilere atıkların doğada yok olma süreleri hakkında bilgi verilmeli, köylerin belirli yerlerine bu konuda bilgi veren, dikkat çekici afişler asılmalıdır. Bunun yanı sıra en temiz işletme yarışması düzenlenerek atıklarını doğaya bırakmayan çiftçiler ödüllendirilebilir.

Kirli bölgedeki çiftçiler tarımsal üretimlerinde gübre miktarını belirlerken toprak analiz sonuçlarını dikkate almamakta ya da toprak analizi yaptırmamaktadırlar. Bu bölgedeki çiftçilere toprak analiz sonuçlarının nasıl değerlendirilmesi gerektiği ve gübre miktarının belirlenmesinde toprak analizinin önemi açıkça ifade edilmelidir. Gerekirse bu konuda üniversitelerdeki uzmanlardan destek alınmalıdır.

\section{TEŞEKKÜR}

$\mathrm{Bu}$ çalışmaya 2130111 proje numarası ile finansal destek sağlayan TÜBİTAK'a teşekkür ederim.

\section{KAYNAKLAR}

Alonso, J.L., Soriano, A., Carbajo, O., Amoros, I. And Garelick, H. 1999. Comparison and recovery of Escherichia coli and thermotolerant coliforms in water with a chromogenic medium incubated at 41 and $45{ }^{\circ} \mathrm{C}$, Appl. Environ.Microbial., Pp:3746-3749.

Anonim 2015a. 2013 yılı SGK İstatistik Yıllı̆̆ı.

http://www.sgk.gov.tr/wps/portal/tr/

kurumsal/istatistikler/sgk_istatistik_yilliklari

(Erişim:07.09.2015).

Brown, L. 1991. The new world order. In State of the world 1991: A Worldwatch Institute Report on progress toward a sustainable society (3-20). New York: W.W. Norton \& Co.

Çepel, N. ve Ergün, C. 2013. Temel Çevre Sorunları, http://docplayer.biz.tr/6679796-Temel-cevre-sorunlari-profdr-necmettin-cepel-celal-ergun.html (Erişim tarihi:18.10.2014)

Goodland, R. 1996. Growth has reached its limits. In J. Mander \& E. Goldsmith (Eds.) The case against the global economy: And for a turn toward the global (207-217). San Francisco: Sierra Club Books.

Görmez, K. 1997. Çevre Sorunları ve Türkiye, Gazi Kitapevi, Ankara.

Imandoust, S.B. and Gadam, S.N. 2007. Are People Willing to Pay for River Water Quality, Contingent Valuation, International Journal of Environmental Science Technology, 4(3), Pp:401-408.

Kates, R. W. 2000. Population and consumption. Environment, 42(3), Pp:10-19.

Kavas, G. 2011. Gıda ve Çevre İnteraksiyonları, 7. Gıda Mühendisliği Kongresi.

Kocaman, H., Akın, Y.K. ve Oğuzhan, A. 2011. Trakya'da Ergene Nehri Kirliliğinin Tarım Üretimine Olan Etkisi: Edirne Örneği, Karadeniz Fen Bilimleri Dergisi, 2 (5), Pp: 89-104.

Macneill, J., Winsemius, P., and Yakushiji, T. 1992. Beyond interdependence: The meshing of the world's economy and the Earth's ecology. New York: W.W. Norton \& Co.

Newbold, P., (1995). Statistics for Business \& Economics, Fourth Edition, 1995, Prentice-Hall

Shang, Z., Che, Y., Yang, K. and Jiang, Y. 2012. Assessing Local Communities' Willingness to Pay for River Network Protection: A Contingent Valuation Study of Shanghai, China, International J. of Environmental Research and Public Health, Pp:3866-3882. 
Tanrıverdi, Ç., Alp, A., Deminrkıran, A.R. and Üçkardeş, F. 2010 Assement of Surface Water Quality of the Ceyhan River Basin, Turkey, Environt Monit Asses, 167: 175-184.

Taylan, Z.S. ve Özkoç, H.B. 2007. Potansiyel ağır metal kirliliğinin belirlenmesinde akuatik organizmaların biokullanılabilirliliği, BAÜ FBE Dergisi Cilt:9, Sayı:2, Pp:1733.

Tietenberg, T. and Lewis,L. 2009. Environmental and Natural Resource Economics, 8th Edition, Pearson, Addison Wesley, New York.
Toroglu, E. and Toroglu, S. 2009. Microbial Pollution of Water in Golbası Lake in Adiyaman, Turkey, Journal of Environmental Biology, 30(1):33-38.

Toroglu, E., Toroglu, S. ve Alaeddinoğlu, F. 2006. Aksu Çayı'nda (Kahramanmaraş) Akarsu Kirliliği, Coğrafi Bilimler Dergisi, 4(1), Pp:93-103

Toroglu, S., Dincer, S. and Korkmaz, H. 2005. Antibiotic resistance in gram negative bacteria isolated from Aksu river in (Kahramanmaras) Turkey, Ann. Microbiol., 55, Pp:229-233. 